Note

\section{Inhibiting Substance toward Tea Pollen Tube Growth from Marine Alga Spatoglossum Pacificum}

\author{
Hiroyuki Tazaki, Takane FuJimori, \\ Mitsuo ChIHARA* and Yoshiaki HarA* \\ Applied Plant Research Laboratory, Yokohama Center, \\ Japan Tobacco Inc., 6-2 Umegaoka, Midori-ku, \\ Yokohama 227, Japan \\ * Institute of Biological Sciences, University of \\ Tsukuba, Tsukuba-shi, Ibaraki 305, Japan
}

Received December 12, 1990

In the course of screening for substances which control the process of germination and tube elongation of the pollen from Thea sinensis, we found a new inhibitor, 6-acetoxylinoleic acid (1), from the marine brown alga Spatoglossum pacificum.

One hundred and twenty-two species of algae were collected from various locations along the coast (Muroran, Chiba, Kamakura, Izu and Okinawa) of Japan in 1986-1987. Methanol extracts of these were assayed for the germination and tube growth inhibition of tea pollen by Konishi's method. " The nine species of Callophyllis crispata, Cladophoropsis raucheriaeformis, Codium fragile, Coeloseira pacifica, Delisa fimbriata, Dictyota dichotoma, Rhodopeltis borealis, S. pacificum and Vidalia obtusiloba strongly inhibited pollen germination and tube growth.

$S$. pacificum $(11.45 \mathrm{~kg}$ ) collected from the shore near Shirahama Shrine in Izu was freeze-dried and extracted with $\mathrm{MeOH}$. The EtOAc-soluble fraction $(31 \mathrm{~g})$ from the $\mathrm{MeOH}$ extracts was fractionated twice in an $\mathrm{SiO}_{2}$ column, and then by high-performance liquid chromatography (HPLC) in an ODS YMC AM324 column (100\% MeOH, refractive index). Further purification of the active fraction by HPLC in a YMC PH A414 column, using $90 \% \mathrm{MeOH}$, gave a coloriess and viscous inhibitor (1) in a yield of $7 \mathrm{mg}$. Compound 1 thoroughly inhibited pollen germination at a concentration of $1.0 \mu \mathrm{g} / \mathrm{ml}$ and reduced pollen tube

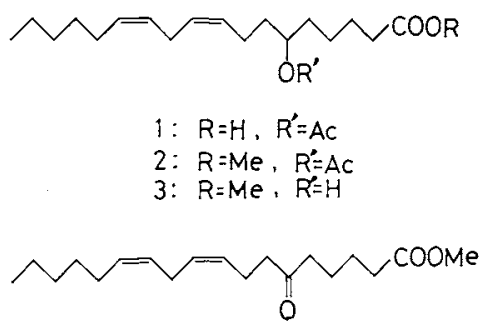

4 growth to $34 \%$ with a concentration of $0.1 \mu \mathrm{g} / \mathrm{ml}$.

The ${ }^{1} \mathrm{H}$-NMR $\left(\mathrm{CD}_{3} \mathrm{OD}\right)$ spectrum showed signals of 34 protons assignable to a methyl at $\delta 0.95(3 \mathrm{H}, \mathrm{t}, J=7.2 \mathrm{~Hz}$, seven methylenes at $1.39(8 \mathrm{H}, \mathrm{m})$ and $1.64(6 \mathrm{H}, \mathrm{m})$, an acetyl at $2.07(3 \mathrm{H}, \mathrm{s})$, two methylenes bonded to a double bond at $2.11(4 \mathrm{H}, \mathrm{m})$, a methylene attached to a carboxyl at $2.32(2 \mathrm{H}, \mathrm{t}, J=7.1 \mathrm{~Hz})$, a methylene between double bonds at $2.81(2 \mathrm{H}, \mathrm{m})$, a methine attached to an acetoxy group at $4.91(1 \mathrm{H}, \mathrm{m})$, and two double bonds at $5.40(4 \mathrm{H}$, $\mathrm{m})$. The presence of a free carboxyl group was confirmed by esterifying 1 with $\mathrm{CH}_{2} \mathrm{~N}_{2}$ to give a monomethyl ester (2). Twenty carbons were observed in the ${ }^{13} \mathrm{C}-\mathrm{NMR}$ ( $\left.\mathrm{CD}_{3} \mathrm{OD}\right)$ spectrum of 1 as follows: $\delta 14.4\left(\mathrm{CH}_{3}\right), 21.2$ $\left(\mathrm{CH}_{3}\right), 23.6\left(\mathrm{CH}_{2}\right), 24.2\left(\mathrm{CH}_{2}\right), 26.0\left(\mathrm{CH}_{2}\right), 26.1\left(\mathrm{CH}_{2}\right)$, $26.5\left(\mathrm{CH}_{2}\right), 28.2\left(\mathrm{CH}_{2}\right), 30.4\left(\mathrm{CH}_{2}\right), 32.6\left(\mathrm{CH}_{2}\right), 34.9$ $\left(\mathrm{CH}_{2}\right), 35.1\left(\mathrm{CH}_{2}\right), 35.3\left(\mathrm{CH}_{2}\right), 75.1(\mathrm{CH}), 128.8(\mathrm{CH})$, $129.8(\mathrm{CH} \times 2), 131.1(\mathrm{CH}), 172.8(\mathrm{C})$ and $178.4(\mathrm{C})$. The GC-FDMS of 1 gave an $[\mathrm{MH}]^{+}$ion at $m / z$ 339, indicating that MW of 1 was 338 , and GC-EIMS gave fragment ions at $m / z$ (rel. int.) $279(5), 258(0.1), 251$ (1), $236(1), 222$ (1), 209 (1), 207 (1), 194 (1), 192 (1), 180 (1), 177 (3), 150 (47), $136(4), 121(8), 107(12), 93(30), 91(15), 80(67)$, $67(47), 55(33), 42(100)$ and $40(27)$. Considering the number of protons and carbons from the NMR data, the molecular formula of 1 was elucidated to be $\mathrm{C}_{20} \mathrm{H}_{34} \mathrm{O}_{4}$. These data indicated that $\mathbf{1}$ was a monoacetoxy $\mathrm{C}_{18}$ fatty acid with two double bonds jointed to the same methylene. The double bonds were shown to be cis since no trans unsaturation could be detected in the IR absorption (2920, $2850,1711,1694,1657,1383,1088,753 \mathrm{~cm}^{-1}$ ) of 1 .

The position of an acetoxy group and double bonds was determined by GC-EIMS of derivatives of 1 . Hydrolysis of 1 with $\mathrm{KOHaq}$ and subsequent esterification with ethereal $\mathrm{CH}_{2} \mathrm{~N}_{2}$ gave alcohol 3. Oxidation of alcohol 3 with pyridinium dichromate $\mathrm{PCC}$ ) in $\mathrm{CH}_{2} \mathrm{Cl}_{2}$ resulted in the formation of ketone 4 . Alcohol 3 gave a fragment ion at $m / z 145$, which was yielded by cleavage of the $\mathrm{C}_{6}-\mathrm{C}_{7}$ bond, helping to locate the $\mathrm{OH}$ at $\mathrm{C}_{6}$. Furthermore, in the case of 4 , cleavage at the $\alpha$ position of the keto function produced fragment ions at $m / z 194,165,143$ and 115 . These fragmentation patterns showed that the position of the acetyl group was $\mathrm{C}_{6} .{ }^{2,3}$ In addition, 4 indicated fragment ions at $m / z 137,111$ and 97 , which were yielded by cleavage of the $\mathrm{C}_{8}-\mathrm{C}_{9}, \mathrm{C}_{10}-\mathrm{C}_{11}$ and $\mathrm{C}_{11}-\mathrm{C}_{12}$ bonds, respectively, confirming the presence of double bonds at $\mathrm{C}_{9}-\mathrm{C}_{10}$ and $\mathrm{C}_{12}-\mathrm{C}_{13}$. Thus 1 was characterized as 6-acetoxylinoleic acid. Compound 1 was chiral, $[\alpha]_{D}^{23}$ $-1.04\left(c=0.5, \mathrm{CHCl}_{3}\right)$, but the absolute configuration at $\mathrm{C}_{6}$ remains to be solved.

$\mathrm{C}_{8}-\mathrm{C}_{11}$ fatty acids, their 2-hydroxy derivatives, and 3-hydroxydecanoic acid (myrmicacin) have shown inhibitory activity toward pollen germination. ${ }^{4)}$ These compounds completely inhibited the germination of Camellia japonica pollen at a concentration of $50 \mu \mathrm{g} / \mathrm{ml}$, whereas 1 showed complete inhibition of T. sinensis pollen germination at the much lower concentration already described. Since linoleic acid has no activity, the acetoxy 
group at $\mathrm{C}_{6}$ is necessary to exhibit the activity. There is a possibility that 1 could demonstrate activity after hydrolyzing the acetate. However, this has not yet been confirmed because 6-hydroxylinoleic acid could not be prepared due to the small quantity of $\mathbf{1}$.

Recently, acetoxy and hydroxy fatty acids with biological activities have beeh found in marine plants, animals and basidiomycete fugus. ${ }^{5-7}$ Such endogenous derivatives of fatty acids might have a common physiological role in various organisms.

\section{References}

1) S. Konishi and H. Yokota, Plant \& Cell Physiol,
21, 255 (1980).

2) M. S. Ahmad, M. U. Ahmad and S. M. Osman, Phytochemistry, 19, 2137 (1980).

3) I. A. Ahmad, M. R. K. Sherwani, S. Q. Hasan, M. S. Ahmad and S. M. Osman, Phytochemistry, 22, 493 (1983).

4) K. Orito, Y. Seki, A. Watanabe, M. Matsumoto and T. Iwadare, Phytochemistry, 22, 2316 (1983).

5) D. B. Boylan and P. J. Sheuer, Science, 155, 52 (1967).

6) A. Lopes and W. H. Gerwick, Tetrahedron Lett., 29, 1505 (1988).

7) W. S. Bowers, H. C. Hoch, P. H. Evans and M. Katayama, Science, 232, 105 (1986). 